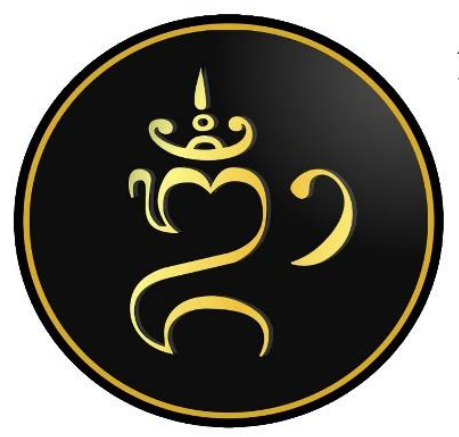

E-ISSN: $2722-8576$

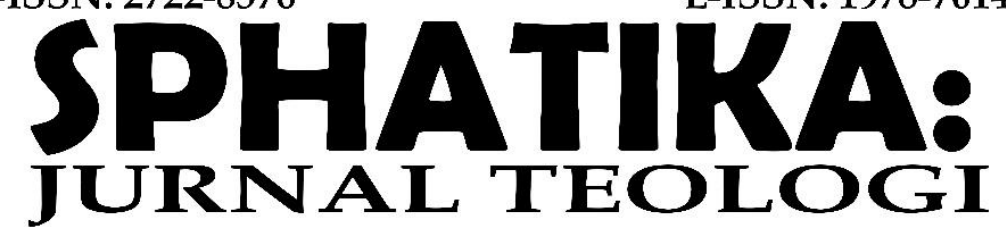

UNIVERSITAS HINDU NEGERI

I GUSTI BAGUS SUGRIWA DENPASAR VOLUME 12 NOMOR 2, SEPTEMBER 2021

\title{
OPTIMALISASI KEHARMONISAN MASYARAKAT PLURAL MELALUI AJARAN TEOLOGI KERUKUNAN
}

\author{
Komang Heriyanti ${ }^{1}$ \\ 1Sekolah Tinggi Agama Hindu Negeri Mpu Kuturan Singaraja \\ 1heriyantikomang@gmail.com
}

\section{Keywords:}

harmony; harmony theology; religious pluralism

\section{Kata kunci:}

keharmonisan;

pluralisme

agama; teologi

kerukunan

\begin{abstract}
The Covid-19 pandemic that has occurred so far has had an impact on various aspects such as the economy, social relations, and moral issues. Various things have also been done to contribute to the impact of covid19, one of which is by carrying out activities during the covid-19 pandemic. This article aims to describe the realization of social theology in activities during the covid-19 pandemic. The benefit of this paper is to provide an overview of social theology in activities during the Covid19 pandemic.
\end{abstract}

Abstrak
Keharmonisan dalam kehidupan beragama menjadi fenomena
penting untuk diperhatikan. Mengingat di Indonesia
berkembang beberapa agama yang berbeda, maka perlu
kiranya ajaran-ajaran teologi kerukunan diterapkan.
Kehidupan masyarakat di bawah pluralisme agama tidak serta
merta selalu harmonis. Dalam keseharian beberapa kasus
disharmoni umat beragama sering terjadi. Disharmoni tersebut
terjadi karena kurangnya toleransi antara umat beragama yang
satu dengan lainnya. Untuk memunculkan kembali sikap
toleransi, seseorang perlu untuk mendalami ajaran agama.
Dengan demikian tidak lagi muncul pikiran yang sempit
terhadap umat agama Hindu. Teologi kerukunan perspektif
Hindu dalam hal ini berusaha memberikan ajaran tentang
persatuan umat manusia. Dalam teologi kerukunan persepektif
Hindu, setiap umat manusia hendaknya menghormati sesama
manusia sebab berasal dari sumber yang sama yaitu Tuhan.




\section{PENDAHULUAN}

Fenomena terkait pluralisme agama di tengah kehidupan masyarakat saat ini sering dipandang sebagai masalah yang cukup serius, di antara berbagai persoalan sosial lainnya. Selain menyimpan akar-akar keragaman primordial yang kuat baik etnik maupun agama, dalam beberapa kasus masyarakat plural tersebut juga menyimpan potensi kon-flik. Terlebih jika dalam masyarakat tersebut belum terbentuk kesadaran multikulturalisme, yakni masyarakat yang tidak sekadar mengerti adanya kelompok-kelompok yang berbeda, melainkan masyarakat yang dapat memberi tempat dan rela hidup berdampingan secara damai dengan varian-varian kelompok yang ada. Indonesia merupakan negara yang plural. Hal ini disebabkan karena masyarakat Indonesia terdiri dari beberapa umat yang berbeda agama.

Sikap toleransi dan menghargai merupakan salah satu upaya yang terdapat dalam agama Hindu untuk mewujudkan keharmonisan antar dan inter umat beragama. Karena bisa dibayangkan bagaimana jadinya apabila umat manusia tidak menjalin dan menciptakan keharmonisan, tentu akan terjadi kehancuran dimana-mana. Di dalam agama Hindu diajarkan berbagai macam konsep untuk menjaga keharmonisan dengan sesama. Konsep inilah yang seharusnya dipegang teguh oleh masyarakat.

Meski ada banyak ajaran-ajaran luhur di dalam agama Hindu yang menuntun umat untuk hidup harmonis, kerukunan umat beragama baik sesama umat Hindu ataupun dengan umat lainnya dalam masyarakat plural belum bisa terealisasi secara maksimal. Melihat masih banyak umat beragama yang bersikap ekslusif dalam kehidupan beragama, maka tulisan ini bertujuan untuk menghadirkan kembali ajaran teologi kerukunan yang ada dalam agama Hindu. Diharapkan ajaran tersebut dapat memberikan suatu kontribusi untuk membuka pikiran masyarakat akan pentingnya keharmonisan dalam hidup bermasyarakat. Selain itu, diharapkan juga tulisan ini membuka kesadaran masyarakat bahwa sesungguhnya seluruh mahkluk hidup berasal dari sumber yang sama yaitu Tuhan.

\section{METODE}

Penelitian ini menggunakan metode kualitatif dengan pendekatan fenomenologi. Muhadjir (1992:24) menyatakan bahwa penelitian kualitatif adalah penelitian yang menghasilkan deskripsi berupa kata-kata tertulis atau lisan dari orang dan pelaku yang dapat diamati berdasarkan fenomena pendekatan holistik (utuh). Metode pengumpulan data dalam penelitian ini menggunakan studi Pustaka. 
Data yang digunakan dalam penelitian ini yaitu data primer yakni buku-buku yang terkait dengan teologi kerukunan umat beragama. Data sekunder yakni data atau informasi yang diambil dari jurnal ilmiah, internet, arsip dan lain-lain. Analisis data dilakukan secara deskriptif kualitatif. Analisis dilakukan dengan melihat fenomena sosial yang terjadi dalam kehidupan masyarakat dimana masyarakat tersebut terdiri dari agama yang berbeda. Data yang telah didapat kemudian dikumpulkan serta dianalisis sehingga memberi pengetahuan yang baru.

\section{PEMBAHASAN}

\section{Teologi Kerukunan Perspektif Hindu}

Teologi kerukunan adalah bagaimana masing-masing pemeluk agama memahami agama yang diyakininya secara komprehensif lalu berusaha juga mencari titik temu pada nilai-nilai agama lain, bukan dalam domain keyakinan agama yang ingin disatukan, yang ingin disatukan adalah nilai-nilai kebersamaan bukan nilai-nilai perbedaannya. Seperti, semua agama pasti mengajarkan kedamaian, keharmonisan, dan kebahagian. Maka, akan lahir nilai-nilai kasih sayang, kesadaran menolong kepada sesama, dan saling menghormati satu sama lain (Heriyanti, 2020).

Sesuai pendapat di atas, teologi kerukunan mengajarkan agar manusia bisa hidup harmonis satu sama lain. Keharmonisan tersebut ditujukan kepada seluruh umat beragama, bukan hanya kepada umat yang memiliki agama yang sama tetapi untuk umat yang berbeda agama. Dengan demikian sangat penting memahami ajaran teologi kerukunan dengan baik sehingga dapat diaplikasikan dalam kehidupan bermasyarakat.

Agama Hindu memiliki banyak ajaran untuk mempersatukan umat manusia. Dalam Veda terdapat berbagai sloka untuk menumbuhkan hubungan yang harmonis dalam kehidupan bersama dalam suatu masyarakat. Sloka Atharvaveda III.30.4 menyatakan tentang persatuan sesama manusia yaitu sebagai berikut:

Yena devā na viyanti no ca vidvișate mithah, tat krṇmo brahma vo grhe samijnanam puruṣebhyah.

Terjemahannya:

Wahai umat manusia, persatuanlah yang menyatukan semua para dewa. Aku memberikan yang sama kepadamu juga sehingga anda mampu menciptakan persatuan diantara anda (Titib, 1998:347).

Sloka Veda ini sebagai petunjuk dari Tuhan kepada umat manusia untuk membangun persatuan dengan sesama manusia. Ini artinya persatuan untuk mewujudkan hubungan yang harmonis antara manusia dengan manusia sebagai kondisi untuk mencapai hubungan yang 
harmonis dengan Tuhan. Ini berarti perpecahan apa lagi permusuhan dalam kehidupan dengan sesama manusia itu suatu kondisi yang membuat orang jauh dari Tuhan. Dengan demikian berarti membangun persatuan yang dinamis, humanis dan produktif dalam hal ini tidak bisa diartikan secara sempit. Kata produktif tersebut bukan berarti hanya menghasilkan benda-benda untuk memenuhi kebutuhan materi dan non materi tetapi juga seperti moral yang semakin baik, mental yang semakin tangguh, dan semakin bijaksana.

Wiana (2007: 126) dalam mantra Reg Veda X.191.2 dinyatakan tentang bagaimana membangun suatu persatuan dalam mewujudkan kondisi kebersamaan yang harmonis, dinamis, humanis dan produktif dalam artian lahir bathin. Mantra Reg Veda tersebut adalah sebagai berikut:

sam் gacchadhvam் sam் vadadhvam

sà் vo manāmisi jānatām,

devā bhāgam yathā pūrve

sañjānāna upāsate.

Terjemahannya:

Wahai umat manusia anda seharusnya berjalan bersama-sama, berbicara bersamasama dengan pikiran yang sama seperti halnya para pendahulumu bersama-sama membagi tugas mereka, begitulah anda mestinya memakai hakmu (Titib, 1998:348).

Selanjutnya mantra Rgveda X.191.4 memberikan landasan yang kuat tentang awal suatu persatuan hidup bersama di bumi ini. Mantra tersebut adalah sebagai berikut:

samāni va àkūtih samānā hrdayāni vah, samānamastu vo mano yathā vah susahāsati.

Terjemahannya:

wahai umat manusia semoga engkau maju dengan niat-niat yang sama. Semoga hatimu (bathinmu) dan pikiranmu sama satu dengan yang lain. Sehingga anda bisa diorganisir (diatur) secara seragam (Titib, 1998:349).

Melihat mantra Veda di atas, maka ada banyak konsep untuk mengajarkan persatuan antar sesama manusia yang dinyatakan dalam ajaran Veda dan kitab-kitab sastranya. Kalau disimak secara cermat bahwa keharmonisan dalam persatuan dengan sesama manusia idak begitu saja dapat dicapai dengan mudah. Sebagaimana diajarkan dalam mantra Atharvaveda dan Rgveda tersebut di atas. Kehidupan bersama yang harmonis, humanis dan dinamis itu hanya dapat diwujudkan kalau masing-masing individu dalam kehidupan bersama siap untuk menjadikan diri sebagai manusia yang ideal struktural.

Individu yang ideal struktural adalah individu yang memelihara dan menjaga kesempurnaan serta kesehatan pikiran dan indriyanya. Kondisi diri yang ideal struktural adalah kondisi diri yang memiliki fisik yang sehat, pikiran yang cerdas dan hati nurani yang murni. Individu yang seperti itulah yang dapat diupayakan untuk membangun niat yang 
mulia untuk maju bersama-sama untuk memikirkan langkah-langkah yang tepat untuk dilakukan demi memenuhi kepentingan bersama dalam rangka mewujudkan tujuan hidup yang disebut Catur Purusa Artha. Inilah yang disebut menyamakan persepsi, visi dan misi membangun hidup bersama yang sejahtera adil dan makmur (Wiana, 2007:128).

Sesuai pendapat di atas, tanpa ada niat yang sama, hati yang sama, pikiran yang sama tidak mungkin bisa menyaakan persepsi. Tanpa adanya kesamaan persepsi tidak mungkin membangun visi yang sama. Tanpa misi yang sama tidak ada misi bersama mebangun kebahagiaan bersama. Inilah konsep kebersamaan dengan mendayagunakan sraddha dan bhakti pada Tuhan. Maksudnya upaya membangun kebersamaan itu sebagai wujud bhakti kepada Tuhan Yang Maha Esa. Inilah yang disebut hubungan yang harmonis, humanis dan dinamis. Tentunya berbeda dengan kebersamaan yang didasarkan pada kepentingan politik, atau berdasarkan tujuan untuk mendapatkan keuntungan material atau kekuasaan dan jabatan tertentu. Dalam sloka kitab Bhagawad Gita disebutkan pula bahwa:

Suhrn-mitrāry-udāsina-madhyasta-dveșya-bandhușu

Sādhușv api ca pāpeșu sama-buddhir viśișyate

Terjemahannya:

Dia adalah orang utama yang bersikap sama antara kawan akrab, teman, dan lawan, antara yang netral dan penengah, yang dibenci dan keluarga yang budiman dan yang jahat (Pudja, 2004: 158).

Uraian sloka tersebut memberikan penjelasan bahwa setiap orang perlu mengembangkan sikap dan sifat pluralistis, sebab sifat itu merupakan sifat dari orang bijaksana. Jika benar manusia itu adalah mahkluk paling mulia, tentu manusia itu akan mangarah kepada sifat-sifat yang dimiliki oleh orang bijaksana yang mampu melihat semua keberadaan yang beraneka ragam bukan sebagai persoalan. Keanekaragaman bukan menjadi musuh, tetapi menjadi taman yang indah (Donder, 2009: 233)

Pada hakekatnya amanat sloka yang dikutip di atas adalah suatu konsep Hindu untuk menyiapkan individu-individu agar bersatu untuk membangun kebersamaan yang harmonis, humanis dan dinamis. Dalam sastra Hindu ada dinyatakan Manavaseva Madhavaseva. Artinya melayani sesama manusia sesungguhnya juga berarti melayani Tuhan. Ini bukan berarti manusia itu sama dengan Tuhan. Manusia adalah ciptaan Tuhan dan ada aspek Tuhan dalam diri manusia yang disebut Atman. Alam atau makrokosmos dalam ajaran sastra Veda disebut Bhuwana Agung, sedangkan manusia atau mikrokosmos disebut Bhuwana Alit. Jiwa dari Bhuwana Agung adalah Brahman yaitu Tuhan itu sendiri. Jiwa dari Bhwwana alit disebut Atman. Dalam Brhadaranyaka Upanisad I.4.10 ada dinyatakan "Brahman Atman Aikyam" artinya Brahman dan Atman adalah sama (Sura, 1996:35). 
Manusia oleh Tuhan diciptakan sama dan berbeda. Artinya ada unsur-unsurnya yang sama tetapi ada juga unsur-unsurnya yang berbeda. Karena adanya perbedaan keadaan dan persamaan tujuan itulah manusia harus saling bekerja sama dalam wujud saling mengabdi untuk mencapai tujuan yang sama yaitu hidup sejahtera dan bahagia lahir batin di bumi ini. Letak kekuatan manusia adalah pada kemampuannya membangun kebersamaan menutup berbagai keterbatasannya. Tuhan telah menciptakan Dharma sebagai "statuta law" atau hukum kebersamaan agar kebersamaan itu dapat saling memperkuat antara satu dengan yang lainnya. Dengan kekuatan yang didapatkan dalam kebersamaan itu manusia akan dengan lebih mudah mewujudkan tujuannya.

Dalam Manawa Dharmasastra VII.14 dinyatakan bahwa Tuhan telah menciptakan dharma sebagai putranya untuk melindungi makhluk hidup ciptaan-Nya (Pudja, 2004:356). Setiap makhluk ciptaan Tuhan hendaknya dengan setia mengikuti dharma putra Tuhan itu dalam setiap dinamika kehidupannya. Selanjutnya dalam sloka Manawa Dharmasastra VII.17 menetapkan bahwa Dharma sebagai penguasa Raja (pemerintahan negara) dalam menata kehidupan bersama di bumi ini (Pudja, 2004:357). Ini artinya dharma yang wajib dilaksanakan dalam kehidupan bersama oleh setiap orang dalam segala dinamika kehidupannya. Karena dharma adalah putra Tuhan, berarti berbhakti pada Tuhan harus diwujudkan dengan mengikuti ketentuan dharma. Kata "putra" dalam bahasa sansekerta artinya penyelamat dari neraka. Artinya barang siapa yang menyelenggarakan hidupnya sesuai dengan ketentuan dharma iapun akan selamat dari jebakan neraka. Begitu pula halnya jika setiap umat manusia bergerak berlandaskan dharma maka akan menumbuhkan kehidupan harmonis.

Donder (2009: 221) Tuhan yang sama dipuja oleh semuanya. Perbedaan gagasan dan pendekatan disebabkan oleh warna setempat dan adaptasi sosial. Mereka yang secara rokhani belum matang tidak akan mau mengakui dewata yang lain selain kepunyaannya. Keterikatannya kepada keimanannya membuatnya buta terhadap persatuan yang lebih besar dari Tuhan. Inilah akibat dari egoisme dalam bidang gagasan-gagasan keagamaan. Bhagawad Gita sebaliknya memastikan bahwa walaupun kepercayaan dan praktek agama adalah jamak dan beragam, realisasi rokhani yang dimaksud oleh semuanya adalah satu.

Terkait pendapat di atas, agama Hindu mangajarkan bahwa sesungguhnya Tuhan memerlakukan sama setiap manusia yang memiliki keyakinan berbeda. Ajaran ini dapat dilihat dalam Sloka Bhagawad Gita berikut:

Yo yo yāmi-yām tanum bhaktạ śraddhayārcitum icchati

Tasya-tasyā calām śraddhām tām eva vidadhāmy aham. Terjemahannya: 
Apapun bentuk kepercayaan yang ingin dipeluk oleh penganut agama, Aku perlakukan kepercayaan mereka sama supaya tetap teguh dan sejahtera (Pudja, 2004: 196).

Sloka di atas mengejewantahkan pluralisme dari keimanan Hindu. Tidak ada yang salah dalam setiap tradisi keagamaan dan tradisi itulah sebenarnya yang menyebabkan satu suku bangsa maupun suatu bangsa bisa bertahan dari generasi ke generasi. Tuhan sebagai Penguasa Maha Tinggi membenarkan keimanan dari setiap orang dan mengkaruniakan apa yang ingin dicarinya. Sepanjang jiwa itu telah naik dalam proses perjuangannya, Tuhan akan membungkuk untuk menemuinya. Setiap bentuk yang disembah oleh manusia yang berbeda keyakinan adalah bermaksud memuliakan Tuhan.

\section{Keharmonisan Masyarakat Dalam Pluralisme Agama}

Secara sosiologis, pluralisme agama adalah suatu kenyataan bahwa kita adalah berbeda-beda, beragam dan plural dalam hal beragama. Dalam kenyataan sosial, kita telah memeluk agama yang berbeda-beda. Pengakuan terhadap adanya pluralisme agama secara sosiologis ini merupakan pluralisme yang paling sederhana, karena pengakuan ini tidak berarti mengizinkan pengakuan terhadap kebenaran teologi atau etika dari agama lain (Sumbulah dan Nurjanan, 2013: 28).

Sesuai dengan pendapat di atas maka pluralitas agama merupakan fakta sosiologis, yang pada akhirnya mencerminkan beragam jalan menuju yang Satu yaitu Tuhan. jalan tersebut merupakan permasalahan tentang yang relatif dan yang absolut. Pada dasarnya pemahaman manusia terhadap agamanya adalah relatif, namun semua ini pada hakikatnya demi yang Absolut. Sedangkan yang Absolut, yang Satu terungkap melalui jalan-jalan yang sifatnya relatif.

Terkait dengan pluralisme agama, Indonesia merupakan negara yang masyarakatnya menganut agama plural. Dewasa ini di media sosial sering diupdate berita tentang konflik antar umat beragama baik dalam bentuk skala kecil maupun skala besar. Kerapkali ditulis bahwa salah satu faktor penyebab konflik di Indonesia karena faktor agama. Pada sisi lain, agama juga tampil sebagai perekat integrasi masyarakat, terutama pada tipologi masyarakat yang agama dan pemahamannya homogen. Agama yang dipakai secara kategoris memang potensial mengundang konflik, bahkan disintegrasi, baik sesama internal pemeluk agama maupun pemeluk antar agama. Pada masyarakat yang heterogen dari segi agama, harus dihindari penggunaan agama sebagai sistem acuan nilai secara eksklusif dan intoleran, yang dengannya potensial memancing konflik dan disintegrasi sosial. 
Melihat permasalahan di atas bahwa konflik agama dalam suatu masyarakat majemuk, adalah suatu yang sangat wajar terjadi. Ini dikarenakan setiap agama mempunyai ciri-ciri tersendiri, yang tidak memiliki kesamaan karakteristik. Agama betapapun mengajarkan tentang solidaritas dan integritas sosial tetapi mempunyai kecenderungan terjadinya disintegrasi oleh umatnya. Sebab untuk memperkuat sejauh mana kebenaran suatu agama itu, doktrin yang dianut dan dipahami dijadikan acuan dan pegangan dalam menghadapi lingkungannya, di mana ia hidup dan berkembang.

Upaya mengikis keberagamaan yang eksklusif di masyarakat merupakan tuntutan yang mendesak. Dalam konteks masyarakat yang plural, diperlukan pemikiran dan sikap inklusif yang berpandangan bahwa diluar agama yang dianutnya juga terdapat kebenaran, meskipun tidak seutuh dan sesempurna agama yang dianutnya. Pandangan seperti ini perlu ditumbuhkan dalam masyarakat (Sumbulah dan Nurjanan, 2013: 26).

Terkait pendapat di atas, konflik dan disharmoni biasanya terjadi karena kurangnya komunikasi dan tiadanya saling memahami di antara komunitas yang berbeda. Masingmasing berdiri berhadap-hadapan antara yang satu dengan yang lainnya. Sekat-sekat pembatas biasanya timbul dari ketiadaan saling mengerti dan memahami antar komunitas agama, sehingga mudah dijadikan alat provokasi dan adu domba yang dapat merugikan semua pihak. Keharmonisan merupakan kebutuhan bersama yang tidak dapat dihindarkan di tengah perbedaan. Perbedaan yang ada bu- kan merupakan penghalang untuk hidup harmonis dan berdampingan dalam bingkai persaudaraan dan persatuan.

Untuk menciptakan keharmonisan hidup yang plural, bangsa Indonesia telah melakukan berbagai upaya yang secara garis besar dapat dikelompokkan menjadi dua. Pertama, upaya konstitusional dan politik, seperti terlihat dalam penetapan undang-undang, peraturan, dan sejumlah petunjuk mengenai penataan pluralitas itu. Kedua, membangun ketulusan pluralitas melalui penumbuhan kesadaran di tingkat esoterik agama-agama secara tulus, untuk kemudian membangun harmonitas kehidupan. Secara konstitusional pemeliharaan keharmonisan hidup umat yang plural itu terlihat dalam penegasan UUD 1945 pasal 29 (Harahap, 2011: 6).

Terkait pendapat di atas, ketulusan dalam memahami dan menyikapi kehidupan bangsa yang multikultural amatlah signifikan bagi kelangsungan harmonitas sosial. Sebab kenyataan sejarah membuktikan bahwa kecurangan dalam menyikapi hidup yang plural seringkali menjadi penghambat harmonitas sosial.

Sesungguhnya setiap umat beragama tidak sulit untuk menciptakan keharmonisan. keharmonisan dapat dicapai dengan mempelajari ajaran agama. Secara normatif, semua 
agama mengajarkan nilai-nilai kebaikan, cinta kasih, perdamaian dan persaudaraan. Agama juga mengajarkan toleransi beragama, yang berarti tidak ada paksaan dalam beragama, sehingga setiap penganut suatu agama harus menghormati keyakinan dan kepercayaan penganut agama yang lain. Dalam teologi masing-masing agama yang berbeda-beda bahkan mungkin saling bertentangan yang diyakini sepenuhnya oleh masing-masing penganutnya harus pula dihormati. Penganut agama yang satu harus menghormati keyakinan teologis penganut agama lain, dan sebaliknya.

Semua orang dapat hidup bersama tanpa ada kecurigaan, dimana tumbuh sikap saling menghormati dan kesediaan berkerja sama demi kepentingan bersama. Hidup rukun haruslah menjadi sikap yang muncul dari lubuk hati yang paling dalam, terpancar dari kemauan untuk berinteraksi satu sama lain sebagai manusia tanpa tekanan dari pihak manapun (Nasution, 2014; 1).

Berpatokan pada pendapat di atas maka kerukunan beragama diidealkan sebagai kondisi hidup dan kehidupan yang mencerminkan suasana damai, tertib, tentram, sejahtera, hormat menghormati, harga menghargai, tenggang rasa, gotong royong sesuai dengan ajaran agama. Kerukunan hidup umat beragama juga mengupayakan hadirnya sebuah tatanan dimana semua golongan agama dapat hidup bersama-sama secara damai tanpa mengurangi hak dan kebebasan masing-masing untuk menganut dan melaksanakan kewajiban agamanya.

\section{PENUTUP}

Teologi kerukunan mengajarkan kepada setiap manusia agar mampu hidup berdampingan secara harmonis dengan umat yang berbeda agama. Terkait hal tersebut, agama Hindu memiliki banyak ajaran yang menuntun umat manusia untuk saling menghargai satu sama lain. Sloka Veda yang mengajarkan kebersamaan dalam agama Hindu sebagai petunjuk dari Tuhan kepada umat manusia untuk membangun persatuan dengan sesama manusia. Ini artinya persatuan untuk mewujudkan hubungan yang harmonis antara manusia dengan manusia sebagai kondisi untuk mencapai hubungan yang harmonis dengan Tuhan. Konsep kebersamaan yang demikian mendayagunakan sraddha dan bhakti pada Tuhan. Maksudnya upaya membangun kebersamaan itu sebagai wujud bhakti kepada Tuhan Yang Maha Esa.

Agama Hindu merupakan salah satu dari beberapa agama yang ada di Indonesia. Indonesia merupakan negara yang masyarakatnya menganut agama plural. Secara sosiologis, pluralisme agama adalah suatu kenyataan bahwa kita adalah berbeda-beda, beragam dan 
plural dalam hal beragama. Sesungguhnya setiap umat beragama tidak sulit untuk menciptakan keharmonisan. Keharmonisan dapat dicapai dengan mempelajari ajaran agama dengan baiksetiap agama tentu mengajarkan nilai-nilai kebersamaan.

\section{DAFTAR PUSTAKA}

Donder, I Ketut dan I Ketut Wisarja. 2009. Teologi Sosial Persoalan Agama dan Kemanusiaan Perspektif Hindu. Yogyakarta: IMPULSE.

Harahap, Syahrin. 2011. Teologi kerukunan. Jakarta: Prenada.

Heriyanti, K. (2020). Moderasi Beragama Melalui Penerapan Teologi Kerukunan. Maha Widya Duta, 4(1), 61-69.

Nasution, Ismail Fahmi Arrauf. 2014. Minoritas dan Politik Perukunan.

Pudja, Gede. 2004. Kitab Suci Bhagawad Gita. Surabaya: Paramita

Pudja, I Gede. 2004. Manawa Dharmasastra. Surabaya: Paramita

Sumbulah dan Nurjanan. 2013. Pluralisme Agama Makna dan Lokalitas Pola Kerukunan Antarumat Beragama. UIN-Maliki Press.

Sura, dkk. 1996. Agama Hindu Sebuah Pengantar. Denpasar: CV Kayumas Agung.

Titib, I Made. 1996. Veda Sabda Suci Pedoman Praktis Kehidupan. Surabaya: Paramita.

Wiana, I Ketut. 2007. Tri Hita Karana Menurut Konsep Hindu. Surabaya: Paramita. 